\title{
Arendt: totalitarismo e ideología
}

\section{[Artículos]}

\author{
Jacinto H. Calderón González ${ }^{*}$
}

Fecha de entrega: 14 de octubre de 2020

Fecha de evaluación: 15 de noviembre de 2020

Fecha de aprobación: 15 de diciembre de 2020

Citar como:

Calderón González, J. H. (2021). Arendt: totalitarismo e ideología. Cuadernos de Filosofía Latinoamericana, 42(124). https://doi.org/10.15332/25005375.6601

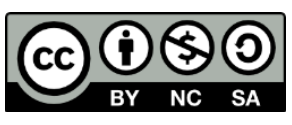

\section{Resumen}

En torno al libro de Hannah Arendt Los orígenes del totalitarismo se buscan explicaciones a la lógica del Estado totalitario, es decir, su modo de operar y sus consecuencias en el ámbito de la libertad, del reconocimiento y del modo de vida que los sujetos pueden esperar en tal Estado. Se encuentra que el terror que se impone logra una deshumanización de los sujetos que, al haber perdido todo lo racional, se encuentran en el territorio de lo inconcebible.

Palabras clave: totalitarismo, terror, propaganda, reconocimiento, ideología.

\footnotetext{
* Doctor en Filosofía, máster en Teoría Política y Cultura Democrática y licenciado en Filosofía por la Universidad Complutense de Madrid.
} 


\section{Arendt: totalitarianism and ideology}

\section{Abstract}

Around Hannah Arendt's book "The Origins of Totalitarianism" explanations are sought for the logic of the totalitarian State, that is, its way of operating and its consequences in the field of freedom, recognition and the way of life that indivuduals can expect in such a State. It is found that the terror that is imposed achieves a dehumanization of the individuals who, having lost everything rational, find themselves in the territory of the inconceivable.

Keywords: totalitarianism, terror, propaganda, recognition, ideology.

\section{Introducción}

Lo que caracteriza al Estado totalitario, lo que podríamos denominar su ratio essendi, es el elemento que lo posibilita, el cual es el terror, en todo el sentido del término. Este es aplicado a una suerte de individuos, que lo padecen y suponen el total de la población. En este sentido, el totalitarismo es la totalidad del terror sobre la totalidad de los individuos de un Estado, excepto uno, precisamente quien lo rige. ¿Qué es el terror? Una forma de miedo que embarga todas las potencias del sujeto, lo inhabilitan para una vida libre y plena y lo convierten en un miembro anónimo, disociado de sí, sin posibilidad de pensar y sin posibilidad de decidir. El terror es la pérdida de la voluntad. Justo lo que el Estado totalitario necesita. Escribe Hannah Arendt: "La dominación totalitaria se orienta a la abolición de la libertad, incluso a la eliminación de la espontaneidad humana en general" (2002, p. 609).

Sin embargo, antes de abordar los elementos del terror en el totalitarismo, cabe plantearse la siguiente pregunta: ¿qué necesidad tiene una forma de gobierno determinada de aterrorizar a sus gobernados? Los inicios del 
comunismo y del nazismo no habían expresado explícitamente la necesidad de un terror. Es cierto que desde su fundamento no habían abogado por unas vías pacíficas para llegar a una sociedad perfecta, ni habían sostenido que su posibilidad de acceso al poder fuera un camino apacible. De hecho, el concepto de lucha de clases y la expansión del espacio vital suponían la violencia, no se puede ignorar. Tal supuesto implicaba que aquél que se adhiriera al movimiento, en parte sabía que la lucha por el poder no sería siempre pacífica, sea porque priorizar una clase social o una raza sobre otra suponía ipso facto que lo que implicaba el cambio no podría hacerse sin un mínimo de violencia. Tanto es así, que el hecho de que los acólitos estuviesen dispuestos a ejercer la violencia es precisamente lo que desde el comienzo les daba un determinado carácter: el de estar dispuestos a todo con tal de conseguir su fin político. Cierto, y si bien la violencia que aquí se plantea no es excusable, esta no implica tampoco nada nuevo; ya decía Hegel (2005) que "la historia es el ara donde se sacrifica la dicha de los pueblos" (p. 80) y, a su vez, no ha habido un salto histórico sin que se haya ejercido violencia de por medio, la conquista del poder es la conquista del territorio y el que conquista oprime al conquistado. Bajo este prisma, no hay nada nuevo.

Lo nuevo es la voracidad con que tal violencia se puso en juego. En un primer momento, aún comprensible, la violencia se ejerce contra el enemigo y aunque triste, puede aparecer como necesaria, es decir, como lo inevitable de toda conquista. Sin embargo, cuando la violencia deja de aplicarse al enemigo y se revuelve contra el movimiento que lo origina y al país que lo contiene, la cosa no es tan fácil de percibir. Igualmente, cuando esta violencia alcanza límites dantescos, ya no es violencia, es terror. El tránsito de la violencia al terror no es fácil de entender ni tan siquiera de ver: ¿̇los que si alistaron a las filas del movimiento habían contemplado 
que su vida futura podría ser una suerte ambigua de víctima o ejecutor? ¿Y qué necesidad había?

La mejor forma de comprender este tránsito es comprender que las dos ideas que están detrás de los movimientos estaban revestidas de una necesidad de imponerse implacablemente, como veremos más adelante. A su vez, tales ideas indican también la necesidad de preparar y lograr una "nueva humanidad" que haga posible su tarea. Tanto la supremacía de la raza como la primacía de la clase, en la medida que quisieron realizarse, tuvieron como elemento focalizador una serie de personas concretas que, en su delirio, pretendieron formar un proyecto político, que de realizarse supondría un ejercicio del poder con una ferocidad nunca vista.

Son, pues, las ideas por las que se forman los movimientos totalitarios las que provocan un terror imprevisible. Tales ideas, por ser radicales, requieren radicalidad en todos sus elementos. La acción política del movimiento totalitario no puede tener otra forma, pues lo que promete es un dominio absoluto. Las ideas, en este sentido, se presentaron de forma sincera, lo que son es lo que son y necesitan realizarse a pesar de quienes se opongan a ellas. Tienen la necesidad de afirmarse en la negación de la oposición, sin dejar lugar a ninguna síntesis. El objetivo es perseguir una "nueva humanidad" que disuelva la anterior. En el siguiente apartado daremos cuenta de la negatividad en que se sostiene la identidad, lo cual ofrecerá conclusiones que el mismo Hegel no pudo prever.

Las ideas radicales encuentran oposición y la identidad del movimiento requiere eliminar toda oposición, más aún porque ambas ideas para ser verdaderas necesitan imponerse, no solo sobre quién se opone a ellas, sino también contra quien las defiende. Nadie puede tener la más mínima duda sobre la veracidad del movimiento que sostiene la idea. 


\section{Población y terror}

Es en este momento cuando es posible percibir que la realización del Estado totalitario, en tanto que se impone, necesita víctimas para consolidar su posición. El terror no es un elemento abstracto, ni tampoco necesita, como pedía Robespierre, que esté acompañado de virtud, el terror debe ser algo tan concreto que se pueda ver y tocar. La forma de materializar la idea, de verificarla, es elevando el nivel del terror a lo cotidiano. El resultado son los millones de muertos que fue dejando el movimiento.

Dicho esto, Hannah Arendt (2002), percibió agudamente que la forma de los regímenes totalitarios de realizar la idea del movimiento equiere de un número determinado de población como víctima propiciatoria. Tal número no está determinado de antemano, es difícil suponer si aquellos que se adherían a las filas del partido sabían a ciencia cierta la hecatombe que iban a provocar.

El punto de partida son las masas, es decir, una ciudadanía que no está adscrita a una clase o a un estamento determinado, pero a la que se puede influir mediante propaganda, hasta el punto de que cualquier cosa que les sea dicha será creída. Tal verdad se impone, posiblemente, porque al estar todo sujeto inmerso en la masa pierde toda su individualidad. Hannah Arendt (2002) lo expresa así: "la característica principal del hombre-masa no es la brutalidad ni el atraso, sino su aislamiento y su falta de relaciones sociales normales" (p. 496). Su aislamiento consistiría a ese fenómeno de estar solo cuando se está rodeado de gente. A su vez, la masa no tiene una estructura determinada, únicamente una serie de intereses por satisfacer, pero por su heterogeneidad y falta de universalidad no logra. Por eso, el movimiento totalitario se encarga de darles una dirección, un sitio al que mirar. En este sentido, "los movimientos totalitarios son organizaciones de 
masas de individuos atomizados y aislados" (Arendt, 2002, p. 505), que a la postre conducen a "la abnegación, en el sentido de que uno mismo no importa, el sentimiento de ser gastable, ya no era la expresión de un idealismo individual, sino un fenómeno de masas" (p. 495). El resultado, a grandes rasgos, y mediante un ejercicio de la propaganda sumado a dosis de terror nos conduce a un individuo particular que manifiesta una "lealtad total", esto es, una lealtad que deja de cuestionarse, no solo los motivos del movimiento, sino que deja de cuestionarse la realidad misma. Tal lealtad solo es "posible cuando la fidelidad se halla desprovista de todo contenido concreto" (p. 505).

El fenómeno de las masas tiene lugar propio en los estudios políticos, sociológicos, psicológicos o filosóficos y ahora no es posible ocuparse de su gestación. Lo que interesa al objetivo que queremos presentar aquí es el número de individuos y su desposesión de la realidad, es decir, su propio enajenamiento, que se logra como decimos, a través de la propaganda y el terror (si bien este mismo sería una forma directa y eficaz de propaganda). Para que el movimiento totalitario sea efectivo necesita de esas masas para disponer de ellas a su antojo.

Pero hay un límite y es, precisamente, el que permite que un movimiento totalitario pueda tener éxito, que consiste en la ecuación entre la población existente y la que puedes eliminar. Para Hannah Arendt (2002) tal elemento es indispensable:

Mientras que todos los grupos políticos dependen de una fuerza desproporcionada, los movimientos totalitarios dependen de la pura fuerza del número, hasta tal punto que los regímenes totalitarios parecen imposibles, incluso bajo circunstancias por lo demás favorables, en países con poblaciones relativamente pequeñas. (p. 485) 
Es una cuestión de números brutos, quizá no tanto de porcentajes. Lograr que las masas vayan por un camino determinado requiere terror y este exige víctimas. ¿Cuántas? Las que sean posibles, pero que no interrumpan la marcha del movimiento o de la vida cotidiana. En este sentido, las cifras que se arrojan en los países que han tenido regímenes totalitarios son pavorosas, y más aún, si tenemos en cuenta que no hay un registro que se pueda considerar fidedigno a la hora de contabilizar las muertes. A Mao Tse Tung se le asocian unos setenta y ocho millones de víctimas (ABC, 2006), al totalitarismo ruso se le suponen unos veinte millones (Agenzia Fides, 2004) y a Hitler unos once millones (Cohen, 2018) ${ }^{1}$. Estos datos pueden convertirse en porcentajes, en torno al $15 \%$ o el $20 \%$ de la población, o sea uno de cada seis o uno de cada cinco, según el dato que consideremos más fiable. Pero como dice Hannah Arendt (2002), el cálculo de porcentaje no es tan relevante como el número. ¿̇Hubieran podido Franco, Mussolini o Fidel Castro eliminar a veintitrés millones de personas de entre sus ciudadanos? Realmente no, de hacerlo no hubiera habido trabajadores ni en el campo, ni en las oficinas, ni en las fábricas.

Por otro lado, no es solo que el terror necesite millones de individuos para su pervivencia, sino que necesita hacerse palpable de una forma sensible y no tanto hacerse explícito. En este sentido, ċsería posible que los titulares de los periódicos adscritos a los movimientos totalitarios publicasen noticias similares a estas: "en 1938 se han eliminado a dos millones de personas en Siberia”, "en lo que va de año se ha ajusticiado a 380 mil opositores del régimen"? Realmente no, entre otras cosas porque no hacía falta: no hay necesidad de publicitar el terror cuando este se convierte en un elemento sensible. Lo cierto es que al caer el nazismo la población no

\footnotetext{
${ }^{1}$ Estos datos son discutibles, dado que las cifras siempre oscilan entre extremos altos o bajos, así como que hay duda sobre las que se pueden achacar al Estado totalitario o a la guerra.
}

Cuadernos de Filosofía Latinoamericana ISSN: 0120-8462 | e-ISSN: 2500-5375 | DOI: https://doi.org/10.15332/25005375 Vol. 42 N. 0124 | enero-junio de 2021 
ignoraba que hubiese habido asesinatos, lo que se supuso que ignoraban eran las cifras dantescas de lo acontecido.

El terror pues tiene una dimensión sensible y es la sombra que acompaña al movimiento totalitario. Millones de muertos dan una realidad tangible: el movimiento va en serio. $\mathrm{Y}$, en este sentido, no es indiferente que las víctimas sean culpables o inocentes, sino que el terror sea visible:

iCamaradas! El levantamiento de los kulaks en vuestros cinco distritos debe ser aplastada sin piedad [...] Debéis hacer ejemplo de estas personas. (1) Cuelgue (me refiero a colgar públicamente, por lo que la gente lo vea) al menos 100 kuláks, ricos bastardos, y chupasangres conocidos. (2) Publicad sus nombres. (3) Aprovechad todo su grano. (4) Liberad a los rehenes según mis instrucciones en el telegrama de ayer. Haced todo esto para que las personas kilómetros a la redonda lo vean todo, lo comprendan, tiemblen, y decidles que estamos matando a los kuláks sedientos de sangre y que vamos a seguir haciéndolo [...]) Atentamente, Lenin. Posdata: Buscad gente más dura. (Academic)

A su vez, en los movimientos totalitarios no hay un sistema legal con garantías mínimas, lo que hay son ejecuciones arbitrarias y masivas. Una vez nombrado Dzerzhinski, fundador de la Cheka, a comienzos de 1919, se tienen noticias de que los chequistas en seis semanas ajusticiaron a cincuenta mil personas (Costelle, 2015). Él mismo recordó lo siguiente: "de nada sirve la justicia" y nos da una aproximación a lo que en un primer momento significaba el terror:

Defendemos el terror organizado, hay que admitirlo francamente. El terror es una necesidad absoluta en los periodos revolucionarios... Aterrorizamos a los enemigos del poder soviético con el propósito de cercenar el crimen de raíz. (Del Rey y Canales, 2015, p. 150) 
Sin embargo, la categoría amigo-enemigo o culpable-inocente adquiere una nueva dimensión. Krylenko, fiscal general de la nación en ese momento, exclamó: "Debemos ejecutar no sólo al culpable. La ejecución del inocente impresionará las masas aún más” (Costelle, 2015).

Algo similar a lo ocurrido en la "Noche de los cristales rotos", el 9 de noviembre de 1938, donde las SA detuvieron a unos treinta mil judíos para su posterior envío a campos de exterminio.

Aterrorizar a las masas, hacerlas sentir miedo, que comprendan que cualquier pensamiento es hostil al movimiento y que este no dudará en ejecutar a inocentes son las normas de una política que no ve límites a la hora de eliminar personas.

Es por eso que las cifras son monstruosas, si bien no podrían elevarse más allá de un número determinado, dado que de ser así se habrían consumido al no haber el número mínimo de personas que pudieran abastecer al régimen.

\section{La propaganda y la organización}

El hecho de que el inocente sea equiparable al culpable es algo que para Hannah Arendt es notorio dentro del totalitarismo. No se trata solo de aterrorizar a la gente, se trata además de utilizar todos los recursos al alcance del Estado para que el sometimiento sea general. El objeto encubierto de la ideología totalitaria es ese sometimiento de las masas, sin embargo, el objeto que se les presenta obedece otra lógica, la supremacía de la raza o la primacía de una clase. Tan fundamental como el terror es ofrecer a las masas un camino por el cual habrían de discurrir todos los sujetos en favor de un guía (Führer), que a la postre habría de ser el único que es capaz de llevar el objeto abierto de la ideología hacia su realización. El medio es pues la propaganda: 
[...] los movimientos totalitarios que luchan por el poder pueden emplear el terror sólo hasta un determinado grado y comparten con otros partidos la necesidad de conseguir seguidores y de parecer plausibles ante un público que no está todavía rigurosamente aislado de todas las demás fuentes de información. (Arendt, 2002, p. 527)

Quizá por este motivo, y como han apuntado diversos autores, el Estado totalitario debe ser un Estado hermético. Las primeras medidas que se tomaron, por ejemplo, al triunfar la Revolución de Octubre, fue suprimir la libertad de prensa y, a su vez, tanto en el comunismo como en el nazismo, se prohíbe la libertad de asociación.

¿Qué les ocurre a unos ciudadanos que tienen como único medio de enterarse de lo que está pasando aquello que les cuenta el régimen que los gobierna? Sencillamente pierden el sentido de la realidad y de la verdad. El movimiento totalitario, consciente que sin las masas a la postre no es nada, no puede permitir que piensen por sí mismas, sino que deben obedecer sin que su pensamiento tenga validez alguna. El objetivo es eliminar al sujeto pensante. Esta tesis es recurrente para Hannah Arendt en el texto que nos ocupa, para ella "la propaganda y el terror ofrecen dos caras de la misma moneda" (2002, p. 529). Aunque matiza que tal cosa solo es cierta en la medida en que el movimiento totalitario no tenga aún todo el control, pues al tenerla, la propaganda es sustituida por el “adoctrinamiento". La propaganda supone, además, que esta tendría su final si todo el mundo estuviese bajo su dominio (lo cual es a la postre su principal objetivo), pues de ese modo, la "contaminación" del "exterior" no sería posible. La propaganda, pues, se ocupa del lado inmaterial del terror mientras existe algo otro a lo que mirar. Por ello, continúa Hannah Arendt (2002), "la propaganda totalitaria puede dirigirse a los segmentos de su propia población cuya coordinación no ha sido seguida suficientemente por el adoctrinamiento" (p. 529). 
Sin embargo, ¿qué se entiende por propaganda? Aunque una delimitación correcta del término nos llevaría lejos de los objetivos de este trabajo, cabe decir que su aparición antigua, consistía en dar a entender la grandeza de alguien a quien se quería ensalzar². Más adelante, en un sentido moderno, la propaganda surge después del Concilio de Trento la Sacra Congregatio de propaganda Fide, en 1622 (Revilla, 2006, p. 2), que tenía como finalidad adoctrinar al pueblo para contrarrestar la "ideología" protestante. Tal elemento provocó que los protestantes lanzasen una contrapropaganda, con idénticos fines. Resaltar aquí este elemento religioso no es gratuito, pues precisamente, si lo que andaba detrás de la propaganda católica era la verdad de la iglesia, en el caso que nos ocupa se trata de que detrás de la propaganda totalitaria se encuentra la verdad del movimiento. En cuyo caso, la definición de la propaganda vendría a ser una serie de actividades políticas simbólicas, visuales, no necesariamente violentas, que tienen como finalidad sustentar a alguien o algo en el poder. En el caso de un Estado totalitario la propaganda, como dice Hannah Arendt (2002), es la otra cara del terror, pero presentada amablemente, al menos hasta cierto punto.

La pretensión, pues, de la propaganda es para el nazismo el adoctrinamiento de las masas para que tomen como verdadero que la raza aria es superior y, de hecho, que sea incuestionable que tal verdad es “cierta y evidente", al margen de que lo sea. Para el comunismo el adoctrinamiento consiste en hacer ver que la clase preferente es la proletaria y que esta debe cumplir con su misión histórica. Tanto la una como la otra se presentan como verdaderas, aun cuando cualquier

\footnotetext{
2 Por ejemplo, como escribe Rafael Revilla (2006), la promoción de las campañas de Alejandro con su correspondiente despliegue simbólico. De Roma, podríamos decir otro tanto, la celebración de un Triunfo no era más que el premio propagandístico que se daba a un general victorioso. Sobre el particular consultar Revilla (2006).
} 
pensamiento tomado en serio no podría deducir que la tal raza aria sea superior como tal o que la clase proletaria sea la clase elegida por el destino para cumplir la meta de la historia. De ahí que tanto el nazismo como el comunismo sean tanto ideologías como utopías. No deja de ser curioso que para que tales ideas se conviertan en verdad se pueden sacrificar arios y proletarios a capricho por el bien de la idea misma. La realidad muestra que ni el ario es superior, ni tampoco el proletariado manda en una dictadura, pero la propaganda insiste hasta que finalmente el sentido común se pierde. Todo vale para este fin: profecías, milenarismo, mesianismo, slogans, promesas, presentar falsos enemigos, etcétera. Por supuesto, son repetidas las veces que haga falta hasta perder el sentido de la realidad.

Hannah Arendt (2002) observa que las masas modernas

[...] no creen en nada visible, en la realidad de su propia existencia; no confían en sus ojos ni en sus oídos, sino sólo en sus imaginaciones, que puede ser atraídas por todo lo que es al mismo tiempo universal y consecuente en sí mismo [pues] lo que convence a las masas no son los hechos, ni siquiera los hechos inventados, sino sólo la consistencia del sistema del que son parte. (p. 541)

Es de creer que, de alguna manera, el anhelo de la masa es querer ser parte de algo más grande que ella misma. Para Hannah Arendt (2002) esto es posible porque el individuo, a pesar de estar dentro de la masa, está en sí mismo aislado. Cree lo que le dicen que crea y no protesta, porque el terror va asociado al mensaje. Básicamente es creer o morir. Es por eso que la perfecta combinación de terror y propaganda destronan el buen sentido, del que hablaba, Descartes en una fe ciega y absurda de las ideas: "la incapacidad principal de la propaganda totalitaria estriba en que no puede colmar este anhelo de las masas por un mundo completamente 
consecuente, comprensible y previsible sin entrar en un conflicto serio con el sentido común" (Arendt, 2002, p. 541) y, a su vez, "la propaganda totalitaria puede atentar vergonzosamente contra el sentido común donde el sentido común ha perdido su validez" (Arendt, 2002, p. 542).

Entonces, ¿cuál es la realidad en un contexto totalitario? De ser cierta la explicación de Hannah Arendt (2002) el totalitarismo habría logrado en poco tiempo lo que las religiones buscan desde sus inicios, masas de acólitos que siguen al guía sin cuestionarse nada. Es casi inocente mencionar la ebriedad de poder que podrían recibir los líderes de los movimientos.

Quizá ahora es más posible entender el objeto de la propaganda. Para Hannah Arendt (2002) su finalidad no sería promocionar una idea, pues deben creerla, pero tal creencia no es útil en sí misma, se trata más bien de que "el verdadero objetivo de la propaganda totalitaria no es la persuasión, sino la organización” (p. 553). Así pues, organizar a las masas es la meta de la propaganda. En este sentido, tenemos una propaganda que se construye para que el sentido común de la masa se atrofie y, una vez atrofiado, las masas sean organizadas, homogeneizadas y dirigidas. Por esto, Hannah Arendt (2002) observa que, a la postre, no es tanto el terror lo que supone una cara de la moneda y la propaganda la otra, sino que la organización sustituye al terror (p. 557).

¿Dónde queda pues el terror? De alguna manera el terror es la garantía del poder, la sombra que todo lo envuelve, en cuyo halo están los medios, propaganda y organización social, para un fin. ¿Cuál es el fin? Esta pregunta debería tener una respuesta fácil, ya sea el dominio total por parte de los arios o por parte de los proletarios. Sin embargo, la realidad desmiente tal supuesto, pues los arios y los proletarios han sido homogeneizados y su voz es nula. ¿Qué es pues lo que se persigue? Quizá 
la pregunta esté mal planteada. Siguiendo a Leibniz, es crucial preguntarse no solo por el qué o el por qué, sino sobre todo por el para qué, ¿̇es decir para qué se organiza, adoctrina, aterroriza y asesina a la masa? La respuesta más fácil sería que tal actividad se ejerce para ensalzar la voluntad y el poder del guía, para que colme su ebriedad de poder, para que el todo se esfume y solo quede la individualidad del guía, para ser un dios entre los mortales.

La organización totalitaria es un elemento, como expresa Hannah Arendt (2002), inseparable de la propaganda. La organización logra que cada parte beneficie al todo, que cada miembro sea parte de una maquinaria, que se reduzca la humanidad a la función maquinal (absolutamente alienante) de que todo su hacer no es en absoluto para sí, sino para la totalidad en la que, pese a todo, solo participa como engranaje.

Lo que sí logra la organización totalitaria es crear una elite que se distingue del resto. Tal elite es el partido, cuya membresía supone algún privilegio, pero a su vez una pérdida de pureza. Hannah Arendt (2002) apunta a cómo todo aquel que, merced al partido, obtenía un determinado puesto, sabía que esa obtención se debía a que el predecesor en el puesto había sido eliminado, lo que implicaba que aceptar el cargo era aceptar ser parte activa del terror:

La humillación implícita en el hecho de deber un puesto a la injusta eliminación del predecesor de cada uno tiene el mismo efecto desmoralizante que la eliminación de los judíos tuvo en las profesiones alemanas; convierte a cada poseedor de un puesto de trabajo en consciente cómplice de los crímenes de un gobierno. (Arendt, 2002, p. 644)

Lo que quiere decir que la organización lograda lo controla absolutamente todo, nadie queda fuera de su engranaje. El hecho de pertenecer al partido 
tiene el significado únicamente de entrever la verdad del movimiento, pero también ha de aceptar la culpabilidad que supone ser parte de él. Nótese que la organización del movimiento totalitario es omnisciente, como un ojo sartriano que todo lo ve, un "todos para nadie y dios contra todos". Michael Mann (2006), en su artículo "El poder autónomo del Estado: sus orígenes, mecanismos y resultados" observa que el Estado tiene elementos significativos, "el poder despótico de la elite estatal” y el "poder infraestructural”. Los Estados, bajo estas dos dimensiones, relacionan su poder según tengan un poder despótico alto o bajo y una coordinación infraestructural, a su vez, baja o alta. Según esto, el Estado autoritario (aquí el totalitario) tendría un poder despótico y una coordinación infraestructural alta, incluso absoluta, lo que supondría que el ciudadano en un Estado así es poco más o menos que nada y no puede escapar. Del mismo modo, cuando Althusser (2006) y Nicos Poulantzas (1979) definían el Estado como una sumatoria entre aparato ideológico y aparato represivo, muy a su pesar, estarían dando la clave de cómo entender el totalitarismo, sea este comunista o de cualquier signo. Y no precisamente porque el Estado "burgués" no adoctrine o no reprima, sino porque el Estado totalitario lo hace realmente mejor.

La propaganda busca la organización de la masa y ya se ha procurado los medios para hacerlo. Sea por la pertenencia al partido, el anhelo a su pertenencia, estar en las “juventudes", o estar marginado, todo obedece a un propósito específico. Así Hannah Arendt (2002) relata cómo para el nazismo ser miembro del partido era algo más bien exclusivo, pero ser simpatizante (un anhelo de ser miembro) era lo frecuente.

De hecho, en la organización totalitaria, el miembro del partido vive en una suerte de enajenación de lo real, pues solo se relaciona con el mundo que ha ideado el guía y su contacto con la realidad está mediado por el 
simpatizante, que recibe del miembro del partido enajenado la realidad que debe implantar.

Este elemento de enajenación es crucial para entender la verdad, la realidad o la inocencia dentro de un Estado totalitario. En efecto, la propaganda, que viene de arriba plantea un mundo que no existe. Al mismo tiempo, la organización totalitaria, secundada por el terror y la propaganda, así como por la policía y el miedo a ser sospechoso, se encargan de que lo verdadero sea lo que se dice desde arriba, aunque desde abajo eso suponga una negación del sentido común:

Las organizaciones frontales rodean a los afiliados al movimiento con una muralla protectora que les separa del mundo normal exterior; al mismo tiempo, constituyen un puente hacia la normalidad, sin el cual, durante la fase previa a la conquista del poder, los afiliados advertirían demasiado agudamente la distinción entre sus creencias y las de las personas normales, entre su fingida perspectiva y la realidad del mundo normal. (Arendt, 2002, p. 560)

Así, por ejemplo, decir a las masas que el pueblo judío es el gran conspirador que quiere acabar con la raza aria (cuando es justo al revés) es algo que se le dice al pueblo para que se lo crea sin más, no para que lo piense, lo discuta o lo ponga en duda. A su vez, la propaganda stalinista explicaba la Revolución de Octubre sin Trotsky, como si no hubiera existido, algo inusual pues prácticamente todos los que tuviesen edad de comprender en 1917 tendrían que negar lo que la realidad les habría mostrado3.

\footnotetext{
3 Las referencias a la "conspiración judía" y a la "conspiración trotskista" están continuamente indicadas en el libro Los orígenes del totalitarismo para ceñirnos a una sola parte del libro en concreto. Estas conspiraciones son necesarias para el totalitarismo y supondrán una forma de alteridad nueva.
} 
Al perder la teoría el contacto con la realidad y obligar a las masas a aceptar esa realidad ideológica se presenta la consecuencia directa de que las masas no pueden pensar. Es más, no solo no pueden pensar, esto es, relacionar lo verdadero con lo falso según les dicta su entendimiento, sino que tampoco deben pensar. Todo pensamiento que no sea la enajenación es hostil y rebelde al movimiento y, por consiguiente, castigable. El totalitarismo es la mejor muestra de lo que ocurre cuando no es posible el pensamiento.

Por ello reina un principio de inocencia general en las masas: ¿son culpables aquellos que no pueden pensar? Para Hannah Arendt (2002) aquí se encuentra la paradoja crucial de las personas que viven bajo un régimen totalitario, una vez han sido desposeídos de su capacidad de pensar han inhabilitado la acción libre.

La fórmula es el adoctrinamiento, la organización y el terror que los aglutina, "el terror es la realización de la ley del movimiento [...] el terror trata de 'estabilizar' a los hombres para liberar a las fuerzas de la naturaleza o de la historia" (Arendt, 2002, p. 688). Para Hannah Arendt el resultado es el terror total. $\mathrm{Al}$ condenar eficazmente todo acto contrario a la ley del movimiento, entonces la capacidad de pensar se reduce y conduce a los sujetos a una enajenación plena, en la cual no son capaces de entablar relaciones normales con sus vecinos.

Aparece nuevamente la ley de sospechosos que tan desastrosamente funcionó en la Revolución Francesa. El buen acólito o seguidor del movimiento no solo tiene que serlo, tiene que demostrarlo y la mejor forma de hacerlo es con la acusación del vecino. A su vez, la policía, sea secreta o no, está pendiente de todo, de forma omnisciente, gracias a la labor ciudadana. No es para menos, porque la propaganda conduce a que todos deban ser conscientes de que hay un enemigo que pretende aniquilar 
a la patria, incluso cuando es sabido que el Estado ya ha logrado la pacificación interior. Para el Estado totalitario siempre hay resistencia. De hecho, si un Estado totalitario lograse imponerse en todo el mundo seguirían teniendo enemigos. ¿Y quién sería este enemigo? A la postre daría igual, solo importa que el terror siga dominando a la población. Por eso, una vez deshumanizados los sujetos, denunciar a su prójimo no es más que una práctica de la cotidianeidad. Si no se es libre para pensar, no se es libre para actuar, pero se tiene que actuar, lo que lleva a suponer que los habitantes de un Estado totalitario son cuerpos sin alma. Sin embargo, ¿esto aplica únicamente a los ciudadanos de a pie o realmente a todos? La respuesta es sencilla, a todos menos al guía, porque de hecho los encargados de la seguridad son vigilados y existe algo así como una policía de la policía y también de esta policía. No es solo que haya policía secreta, es que cuando más secreto es el organismo más poder tiene. Todos se controlan, todos son sospechosos, todos son parte de la maquina estatal, cumplen una función cuya esencia no es el pensamiento.

A este respecto, escribe Hannah Arendt (2002):

[...] presionando a los hombres unos contra otros, el terror total destruye el espacio entre ellos; en comparación con las condiciones existentes dentro de su anillo de hierro [...] El gobierno totalitario no restringe simplemente el libre albedrío y arrebata las libertades; tampoco logra, al menos por lo que sabemos, arrancar de los corazones de los hombres el amor por la libertad. Destruye el único prerrequisito esencial de todas las libertades, que es simplemente la capacidad de movimiento, que no puede existir sin el espacio. (2002, p. 690)

Solo bajo este prisma se puede comprender lo arbitrario de la justicia en un Estado totalitario. La justicia sencillamente es irrelevante, y Hannah Arendt, se había dado cuenta de ello, en tanto que ni los nazis ni los bolcheviques se tomaron la molestia de suprimir la Constitución de 
Weimar o la Constitución de 1936. Lo justo es lo que el movimiento requiere y lo que el movimiento requiere es lo justo. No hay, tan siquiera, espacios para interpretar:

La culpa y la inocencia se convierten en nociones sin sentido; "culpable" es quien se alza en el camino del proceso natural histórico que ha formulado ya un juicio sobre las "razas inferiores", sobre los "individuos incapaces de vivir", sobre las "clases moribundas y los pueblos decadentes". El terror ejecuta estos juicios, y ante su tribunal todos los implicados son subjetivamente inocentes; los asesinados porque nada hicieron contra el sistema, y los asesinos porque realmente no asesinan, sino que ejecutan una sentencia de muerte pronunciada por algún tribunal superior. (Arendt, 2002, p. 688)

$\mathrm{Al}$ imperar el terror no hay culpa y no hay inocencia, solo necesidad natural o histórica. Por eso un inocente, al preguntar por qué es condenado solo se le podría responder que tal condena era una verificación de la marcha del movimiento y que su muerte (¿sacrificio?) era necesario.

\section{Ser-para-nadie y la alteridad obsesiva}

\section{La "Aufhebung" de la dialéctica del amo y del esclavo}

Para intentar encajar los elementos precedentes es importante señalar el carácter intersubjetivo que presenta el movimiento totalitario para

\footnotetext{
${ }^{4}$ Esta suerte de liberación de la culpa al asesino dio, desde luego, mucho que hablar. Sería como si a la hora de juzgar los crímenes del nazismo y a sus criminales hubiese un impedimento a tal juicio, porque los criminales estaban enajenados. A su vez, todo miembro del Estado es igual de responsable por no rebelarse, pero como rebelarse era prácticamente imposible, no hay libertad a la que condenar. Pensemos en las acciones y el destino Winston Smith en 1984.
} 
mostrar la futilidad de la muerte y la preminencia del terror. Se trataría, pues, de explicar por qué un ser humano se comporta así con otro.

Hegel y, se podría decir, cualquier pensador previo al acceso del poder de los movimientos totalitarios no podrían haber imaginado lo que sucedería en la dinámica de esos movimientos. Y ello, no porque no hubieran sido conscientes de la violencia inherente a la marcha histórica, sino por la forma en la que esta se habría de presentar. Así, cabe suponerse un nuevo tipo de conciencia que surge más allá de la dialéctica del señor y el siervo.

Tal dialéctica explica, en un primer momento, que cuando la conciencia se da cuenta que ella misma es su propio objeto deja de ser conciencia y deviene en autoconciencia (Selbstbewusstsein). Si lo propio de la conciencia era la actividad teórica, lo propio de la autoconciencia es la realización de la certeza que había obtenido del conocimiento de sí. La primera sería el ser-en-sí, la otra el ser-para-sí. El ser-para-sí pretende que el mundo sea para ella, la autoconciencia es deseo, apetencia (Begierde). Pero en esta pretensión se cruza con otra autoconciencia que tiene la misma pretensión, que es también deseo. De pronto, en el encuentro entre dos autoconciencias se hace presente el espíritu, eso que Hegel llama el nosotros que coincide con el hecho de que las autoconciencias solo son autoconciencias para otra autoconciencia, por eso,

[...] en tanto que una autoconciencia es el objeto, éste es también, en la misma medida, tanto yo como objeto. - Con lo cual ya está presente para nosotros el concepto de espíritu. Lo que a continuación llegará para la autoconciencia es la experiencia de lo que el espíritu es, esa substancia absoluta que, en la libertad y autonomía perfectas de la oposición de ellas, a saber, de autoconciencias diversas que son para sí, es la unidad de las mismas; yo que es nosotros, y nosotros que es yo. (Hegel, 2010, p. 255) 
Lo que se ha logrado es el reconocimiento, es decir, la necesidad de que el otro te vea como lo que se es, a saber, ser racional y libre. Sin embargo, es precisamente porque el otro es también racional y libre por lo que surge el conflicto. Ambas quieren ser reconocidas, pero en sentido estricto para mirar necesitas ser mirado, necesitas que el otro te vea como libre, pero al verte así, el que mira de esta forma es no-libre (es decir, no mirado, según el símil de la visión). A lo primero también se le llama ser-para-sí, a lo segundo ser-para-otro. La lucha a muerte entre autoconciencias, necesaria para lograr el reconocimiento, tiene como resultado que ambas mueran, que una viva y la otra muera, que las dos mueran o que una viva y la otra también, solo que en este caso es porque ha tenido miedo y ha preferido vivir. La dialéctica del señor y del siervo muestra la tensión entre preferir la vida y preferir la libertad. La autoconciencia que prefiere la libertad sobre la vida es la conciencia del señor, el ser-para-sí; en cambio la que prefiere la vida a la libertad es la conciencia del siervo, el ser-para-otro. La historia prueba distintas formas esta dialéctica. La vencedora se pone encima de la perdedora a la que esclaviza. El que vence se queda con todo, pero cede al perdedor su reconocimiento como autoconciencia y su vida, pero no así su libertad. El que pierde, el ser-para-otro, es un siervo y esa sería su inmediata esencia. Los modos por los que el señor gobierna y mantiene en su sitio al siervo son el temor y el trabajo. La liberación del ser-para-otro es el resultado de ese temor y ese trabajo, y serían la formación y la disciplina.

Sin embargo, ¿qué ocurre en un régimen totalitario? Como todo organismo racional necesita ser reconocido, necesita un ser-para-otro que lo vea alzarse en su señorío. Mas, ¿esto se cumple? En la fase previa al totalitarismo, el imperialismo, a las que Hannah Arendt (2002) dedica la segunda parte del libro Los orígenes del totalitarismo, verifica esta posición señor-siervo: el imperialista se siente superior a los miembros de 
los pueblo que forman su imperio y, desde luego, esta superioridad era clara desde antes incluso del Imperio Romano.

Pero el organismo totalitario no tiene como su esencia un deseo conforme a lo esperable, sino un movimiento que quiere saltar las barreras nacionales y convertirse en el amo del mundo, un amo absoluto. El reconocimiento, en un primer momento, le llega desde dentro y, a su vez, le llega desde fuera a nivel internacional. Es, entonces, cuando ya ha logrado ese reconocimiento, cuando ya ha sido tomado en serio, cuando se desvincula de la dialéctica tradicional y convierte tanto al que debía ser amo como al que debía ser esclavo en un ser-para-nadie.

La prueba se encuentra en el hecho de que ni los nazis, ni los comunistas hacían esclavos en sentido estricto. Sino que a medida que iban encontrando sujetos que representaban una oposición al régimen, estos eran llevados a un campo de concentración y, a veces, eran puestos a trabajar, otras eran directamente asesinados. Más allá de su culpabilidad o su inocencia. Los sujetos dentro del régimen totalitario, como los que están fuera y son conquistados, no van a tener atributos de señor o de siervo, sencillamente no van a tener atributos.

La diferencia con sistemas precedentes es notoria. Rousseau se había fijado en que la diferencia entre un muerto y un esclavo era que este último se "le ha matado con utilidad" (2011, p. 268); por otro lado, supuso un avance en la historia de la humanidad que al vencido no se le matase, sino que se condenase a esclavitud, dado que al menos se conservaba la vida y no se extinguían los pueblos. La historia, a su vez, ha sido acompañada por cadenas de la esclavitud, incluso hoy en día. Aunque, como dice Rousseau (2011), el esclavo tiene utilidad, sirve para trabajar y, por ello, libera al amo de la cadena de la existencia, pues el lujo del amo es precisamente no tener que trabajar para vivir. 
¿Qué está pasando cuando se deja de hacer esclavos y se decide exterminarlos? No perdamos de vista que para Rousseau (2011) si un hombre no es libre, no es un hombre.

Los campos de trabajo, por lo que se sabe, no eran rentables 5 , sino que se gastaba más en mantenerlos de lo que se conseguía de ellos, por lo que se supuso que tales sitios no estaban destinados a producir nada, sino a matar poco a poco a los integrantes del campo. Nunca dejara de sorprendernos los trabajos absurdos que los nazis ponían a los judíos, que no producían nada, amén de la leyenda que aparecía en las puertas de los campos: "Arbeit macht frei [El trabajo os hace libres]".

El proceso de deshumanización conduce de lo que Hegel denominó serpara-otro (el siervo) a un ser-para-nadie en el totalitarismo. No hay reconocimiento, no hay utilidad en el proceso de sometimiento al vencido, solo se busca su exterminio. De hecho, no deja de ser sorprendente el celo que se emplea en hacer efectivo el tal exterminio, sea por raza, por ideología o por clase.

Sin embargo, en el otro extremo, el ser-para-sí, también se transmuta en un ser-para-nadie. Cierto que los acólitos del régimen ganan un poder que no dudan en ejercer, pero estando ellos mismos sometidos al terror, intuyen que este poderío es efímero y su deshumanización consiste en que, lejos de ser señores frente a sus siervos, son siervos frente a otros siervos $\mathrm{y}$, al igual que ellos, no tienen potencia de pensamiento ni de libertad, solo voluntad de ejecutar órdenes. La banalidad del mal es precisamente está indolencia frente al terror. El ejecutor no cuestiona órdenes, por horribles que sean, solo las ejecuta, deja de ser-para-sí y se convierte en un modo de ser que no tiene libertad (lo propio del señorío), que acomete acciones sin

\footnotetext{
5 Ver Del Rey (2016). La ingente cantidad de libros y documentos audiovisuales siempre confirman que el trabajo de los presos era estéril, con contadas excepciones.
}

Cuadernos de Filosofía Latinoamericana ISSN: 0120-8462 | e-ISSN: 2500-5375 | DOI: https://doi.org/10.15332/25005375 Vol. 42 N. ${ }^{\circ} 124$ | enero-junio de 2021 
beneficio, incluso pierde su espontaneidad y asiste al horror al trabajar en una dirección que no tiene humanidad y que, incluso, si muestra debilidad o muestra negligencia (en un campo de concentración por cualquier nimiedad) también puede llegar a ser víctima. De hecho, el ejecutor tiene como cometido hacer que el sujeto a castigar abandoné su humanidad para convertirse en algo infrahumano, una bestia, un animal, una especie inferior. Para el régimen, que el condenado pierda toda su humanidad es deseable, porque así es más fácil eliminarlo.

Kapuscinski (2017), en su libro El imperio dedica muchas páginas a esta suerte de extrañamiento que se da en los habitantes de la Unión Soviética cuando se ha realizado ya el Estado totalitario. El libro está lleno de relatos de sus incursiones a la Unión Soviética y relata las condiciones de vida y la naturaleza de la crueldad bajo el régimen soviético. Entre otros elementos interesantes, el que se quiere rescatar aquí es el que hace referencia al silencio y a la ausencia de miradas entre los ciudadanos entre sí y a la desconfianza hacia los extranjeros, a propósito de un relato de Pruszynski, nos recuerda lo siguiente:

Toda esa gente parecía estar cortada por el mismo patrón. Hombres y mujeres llevan la misma clase de chaqueta, obviamente de abrigo, y las mismas botas altas de obrero. Sus rostros también se antojan idénticos. Muestran concentración y falta de deseo de entablar contacto alguno. No se sabe si están contentos o irritados. Ni siquiera se puede detectar en ellos una sombra de interés. (p. 148)

Percibe también que es un régimen donde hablar es peligroso: “¿Cuántos de ellos (o de sus familiares o amigos) no habían ido a parar en un lager sólo porque, durante una reunión o incluso durante una conversación privada, se les había ocurrido preguntar por esto o por aquello?” (Kapuscinski, 2017, p. 157). 
De la perspectiva de este ser-para-nadie parece que se ha resuelto de un golpe la tensión histórica entre el amo y el esclavo. En el régimen totalitario no hay ya un ser-para-sí ni un ser-para-otro, sólo vacío. Quizá por esto el amo omnipotente que es el guía, es también una persona aislada e, incluso, la más incomprendida, no puede tener amigos, porque la amistad y la libertad requieren igualdad 6 , y no tiene quién lo iguale, de la misma forma que los que caen bajo su yugo no pueden relacionarse tampoco entre ellos ni con él. Quizá las historias que se suelen contar de un Stalin que obligaba a sus invitados a beber y a bailar vendrían de la necesidad de poder relacionarse, en términos humanos, con alguien (Kapuscinski, 2017, p. 239).

\section{La alteridad obsesiva}

Aunque establecimos que se suprime la dialéctica del señor y del siervo de Hegel, no por ello se desdibuja la necesidad del movimiento de ser reconocido y, para ello, al haber suprimido todo anhelo de oposición interna necesita de un enemigo, real o ficticio con el que legitimar el terror al que queda sometida la población. Hannah Arendt (2002) observa que el movimiento no puede detenerse y, por ello, la guerra y la expansión le son inherentes. Hitler lo dejó claro con la idea del "Lebensraum" y el comunismo, sobre todo, con la idea de "revolución permanente" de Trotsky (si bien luego suprimida en su sentido original) o con la misma formación de la URSS y la anexión de distintos países. La idea de ambos movimientos es que alcanzarían su sentido pleno cuando no hubiese obstáculos al régimen. En sus primeros años, se estabiliza la población con el terror, pero una vez asentado y al comenzar sus periodos "imperialistas"

\footnotetext{
${ }^{6}$ Ver Aristóteles (2003). El sentido de la polis griega era la igualdad y solo con esa igualdad era posible que los ciudadanos hablasen entre sí para posibilitar la democracia (Arendt, 2012).
}

Cuadernos de Filosofía Latinoamericana ISSN: 0120-8462 | e-ISSN: 2500-5375 | DOI: https://doi.org/10.15332/25005375 
la extensión del terror sobrepasa las fronteras. Hitler, merced a la ley de la naturaleza, pone toda la carga de la propaganda en el sustrato ideológico de que los judíos son conspiradores que quieren aniquilar a los arios, por lo que su misión universal es eliminarlos para no ser eliminados. Hitler escribe en Mi lucha (1995):

Una cosa comprendí entonces con claridad: la dirección del Partido, con cuyos defensores secundarios había yo disputado agriamente por espacio de meses, se hallaba casi por entero en manos de una raza extranjera, pues para mi satisfacción íntima, conocí finalmente que el judío no era alemán. (p. 26)

A lo que más adelante añade, "de ahí que yo me crea en el deber de obrar en el sentido del Todopoderoso Creador: Al combatir a los judíos, cumplo la tarea del Señor" (p. 28). La lucha propagandística, como ya hemos visto, conduce a que la población crea todas estas cosas. En otro nivel, el nazismo como ideología necesita borrar de la faz de la tierra aquello que pretendidamente le lleve la contraria, es decir, todo. A esto lo denomina Hannah Arendt (2002) "ley de la evolución natural" que es estructuralmente similar a la "ley de la evolución histórica".

En esta línea, si se tiene claro que la evolución va a conducir a lo que el movimiento totalitario pretende, se trata de impulsarlo. La consecuencia es la guerra.

La justificación de la misma es la esencia de la ideología y, a su vez, es lo que pone en marcha la propaganda. Su necesidad de reconocimiento la empuja a ir cada vez más lejos, si tiene los medios para hacerlo. De esta manera, en la guerra tiene libertad el movimiento para hacer lo que quiera y extender el terror por todas partes. "Puede llegarse incluso a conjeturar que una de las razones de Hitler para provocar esta guerra fue el que le 
permitía acelerar la evolución de una forma que hubiera resultado impensable en tiempo de paz”(Arendt, 2002, p. 616).

A su vez, esta guerra no trae beneficios, se podría decir que solo sirve para afianzar la ideología. En el nuevo territorio se sigue la lógica del terror, sigue la danza de la muerte: "Si el conquistador totalitario se comporta todas partes como si se estuviese en su propio país, de la misma forma debe tratar a su propia población como si fuera un conquistador extranjero" (p. 624). La expansión es la ocasión.

El totalitarismo no puede vivir en paz, no se conforma con un poder limitado, lo quiere todo y, por ello, si el enemigo no está claro, se lo inventa. Para el habitante del régimen totalitario es crucial demostrar que no tiene antepasados judíos, o que no tiene abuelos burgueses. Pero tal demostración es inútil. El régimen puede disponer de quién quiera y presentarlo como un enemigo ${ }^{7}$. Sin embargo, la propaganda se centra en propagar la ideología racista o clasista. Incluso hoy día, en los regímenes con visos totalitarios o dictatoriales, serían fácilmente identificados por la forma en la que culpan de sus calamidades a "los imperialistas", "los fascistas", "los enemigos de la libertad". El recurso de que existe un otro al que culpar es inherente a este tipo de movimiento, sería inútil demostrar la

\footnotetext{
${ }^{7}$ Kapuscinski cuenta lo que acontece cuando se llega a un aeropuerto soviético: "El aeropuerto, control de pasaportes. En la ventanilla, un soldado joven del servicio de fronteras. Empieza el concienzudo examen del pasaporte: lo hojea, lo mira, lo lee, pero, sobre todo, busca la fotografía. iPor fin, aquí está! El soldado contempla la fotografía y me mira a mí, la fotografía y a mí, la fotografía y a mí. Algo no le cuadra. iQuítese las gafas!, ordena [...] creo adivinar en qué trabaja: busca al enemigo. El enemigo no lleva escrito en la frente su condición, todo lo contrario: el enemigo va enmascarado. La misión, por lo tanto, consiste en desenmascararlo. Ésta es la habilidad en la que entrenan a mi soldado y a miles de sus compañeros. Aquí tenéis cien fotografías, dice el sargento, una de ellas corresponde a un espía. El que dé con ella recibirá un permiso de una semana. Los muchachos se desojan, se despestañan, gotas de sudor corren por sus sienes. iUna semana de permiso! ¿éste? 0 tal vez ése. Éste no, éste parece un hombre de bien. ¿Acaso crees que el espía tiene cuernos en la cabeza? El espía puede tener un aspecto de lo más normal, iincluso puede sonreír bondadosamente! Claro que no aciertan, porque entre aquellos cien hombres no hay ningún espía" (2017, p. 100).
} 
verdad de que tal otro sea un enemigo, porque la referencia no es a algo concreto, sino a la idea del otro o a su ideología: no hay pues un este como enemigo, sino el enemigo. Por ser abstracto se puede concretar en lo que sea menester para cada caso y, de ser concreto, el enemigo sería particular y limitado, tal eventualidad habría de solucionarse rápido y eficazmente, y esto no interesa. Interesa que el enemigo no se acabe hasta que se logre el control total.

Y aquí aparecen dos preguntas interesantes. Primero, ¿podría un régimen totalitario limitarse a sí mismo? Segundo, ¿qué ocurriría si lograse el dominio del mundo?

Respecto de la primera pregunta, si el régimen totalitario se restringe a sí mismo, si deja de abastecerse desde la alteridad y abandona la lucha, sólo podría juzgarse como lo que es y la culpa sería enteramente suya, lo que implicaría descrédito en las masas. Provocaría lo que más teme, a saber, que su población piense. Es de suponer que tal escenario habría de conducir a más terror y a la creación de más enemigos. Notemos, además, que el ciudadano que piensa, para el régimen, no lo hace de forma autónoma, sino que lo haría desde otro elemento ideológico, considerado enemigo. En este sentido, un intelectual contrario al movimiento no es un intelectual aislado, sino que es un conspirador judío, o comunista, o imperialista, o trotskista, porque la individualidad no puede ser permitida. Todo enemigo individual cae bajo una denominación más amplia que le incluye, aunque no le represente.

En el segundo caso, si un régimen totalitario lograse el dominio mundial habría que pensar que la vida y la libertad estarían en una disociación radical y la humanidad, como tal, perdería su esencia, la humanidad sería algo remoto. 


\section{La ideología}

El final del libro Los orígenes del totalitarismo consiste en una reflexión sobre la ideología y una defensa del culmen de la vita activa de los individuos, que es lo que se ha impedido y constituye la fuente de su criminalidad.

Este análisis final se centra en la idea de que ni el concepto de ley de evolución natural ni la ley de evolución histórica habían dedicado un aspecto de su ideología a la autonomía del sujeto, es decir, a proporcionar una moral valida y apta para la racionalidad de los sujetos. Respecto de las obras de Marx hay que decir que, si bien están impulsadas por un concepto de justicia hacia los proletarios y una denuncia de la injusticia del capitalismo, lo cierto es que no propone una moral. Esta ha de ser supuesta o interpretada, aunque Marx, dado su desarrollo como filósofo, no tendría por qué poner trabas a que los sujetos pensasen o actuasen. Si bien el concepto "dictadura del proletariado" no ayuda precisamente a suponer que los proletarios pueden adscribir una ética de corte kantiano o aristotélico. Esta ausencia permitió, no hay duda, que Lenin, Trotski o Stalin adecuasen "lo ético" a los intereses del partido. El nazismo opera de forma similar, si bien incluye la tradición histórica de Alemania, tanto filosófica como artística, no muestra una preocupación especial por la ética. Más bien habla del ario, del "buen alemán" como elemento de comprensión. Por eso, en ambos casos, lo bueno y lo malo son lo que decide el partido, que se adapta o se contradice sin que por ello se le acuse de nada.

Pero para Hannah Arendt (2002) esta ausencia de ética es crucial para entender el totalitarismo, pues al no permitir el pensamiento libre, ni dar unas normas mínimas a las que atenerse, fueran estas morales o jurídicas (sobre todo, porque ni los nazis ni los comunistas, abolieron la 
Constitución, sencillamente la ignoraban), los sujetos pensantes dejan de pensar, pues hacerlo implica poner en juego no solo el intelecto, sino también la libertad ${ }^{8}$. El problema es que, los sujetos libres piensan, y al pensar pueden tener serias dudas sobre la pretendida validez del movimiento. Por eso entiende Hannah Arendt (2002) que

[...] abolir las barreras de las leyes entre los hombres -como hace la tiranía - significa arrebatar el libre albedrío y destruir la libertad como realidad política viva; porque el espacio entre los hombres, tal como se halla delimitado por las leyes, es el espacio vivo de la libertad. (2002, p. 690)

Como hemos visto, el interés del totalitarismo es dominar todo lo que esté a su alcance mediante el terror, la propaganda y la organización. Tales medios no están dedicados a liberar a los hombres de las nubes del error y conducirles "al cielo de la verdad". El totalitarismo deja claro que el pensamiento y la libertad son superfluos y más bien inútiles y reaccionarios. Lo mejor es que no piensen, el partido ya lo hará por todos y para ello adoctrina a las masas para que sean tan dóciles como corderos: "el propósito de la educación totalitaria nunca ha sido inculcar convicciones, sino destruir la capacidad para formar alguna" (Arendt, 2002, p. 692).

Tener una convicción te puede conducir, merced al propio discurrir del pensar a ponerla en duda. En cambio, si no tienes una convicción no puedes ponerla en duda y el Estado decidirá cuál será tu función: "lo que la dominación totalitaria necesita para guiar el comportamiento de sus súbditos es una preparación que les haga igualmente aptos para el papel

\footnotetext{
8 Hannah Arendt lo expresa así: "la ilegalidad totalitaria, desafiando la legitimidad y pretendiendo establecer el reinado directo de la justicia en la Tierra, ejecuta la ley de la Historia o de la Naturaleza sin traducirla en normas de lo justo y lo injusto para el comportamiento individual" (2002, p. 685).
} 
de ejecutor como para el papel de víctima" (Arendt, 2002, p. 693). Y es que para el totalitarismo la inocencia o la culpabilidad son arbitrarios, pues precisamente una forma sádica de implantar el terror es torturar a alguien y que este no sepa tan siquiera que ha hecho.

Pues bien, "esta doble preparación, sustitutivo de un principio de acción, es la ideología" (Arendt, 2002, p. 693). Es decir, es la preparación de los individuos para que rechacen sus propias ideas y adopten un punto de vista ideológico al renunciar con ello al conocimiento y la verdad. En este sentido, la ideología es un sustitutivo del pensamiento, no se trata de saber, se trata, más bien, de creer.

Por eso, para Hannah Arendt (2002), las ideologías "tratan el curso de los acontecimientos como si siguieran la misma 'ley' que la exposición lógica de su idea”. Las ideologías pretenden conocer los misterios de todo el proceso histórico - los secretos del pasado, las complejidades del presente, las incertidumbres del futuro- merced a la lógica inherente a sus propias ideas" (Arendt, 2002, p. 694). Las ideologías y sus ideólogos tienen como tarea ofrecer una explicación de la realidad y una regla ortodoxa sobre ella que sólo es válida si coincide con los intereses del partido, pero que a su vez tiene que tener el compromiso de que todo esté explicado, de tal forma que el acólito no tenga necesidad de pensar por sí mismo, sino que únicamente debe creer. Una ideología fuerte no se puede permitir "dejar cabos sueltos". La ideología, entonces, según Hannah Arendt (2002) es también una "Weltanschauungen [cosmovisión]". Y, añade, que la victoria de la ideología es previa a la toma del poder por el partido que la representa, esto es, que ya tiene la suficiente fuerza de representación antes de que abogue por el poder (p. 695). 
La necesidad de explicarlo todo es por eso una de sus características, en tanto que la ideología también es "la lógica de una idea", pero la otra es la que tiene verdadera fuerza, a saber, que

[...] en esta capacidad, el pensamiento ideológico se torna independiente de toda experiencia de la que no se puede aprender nada nuevo incluso si se refiere a algo que acaba de suceder. Por eso, el pensamiento ideológico se torna emancipado de la realidad que percibimos con nuestros cinco sentidos e insiste en una realidad más verdadera, oculta tras todas las cosas perceptibles, dominándolas desde ese escondrijo y requiriendo un sexto sentido que nos permite ser conscientes de ella. (Arendt, 2002, p. 696)

El acólito de la ideología, en cierto sentido, es superior al resto, porque ve lo que se oculta tras el velo, pero, en cierto sentido, como no sustenta esta visión en sus sentidos no puede demostrarlo más que siguiendo la lógica inherente a su ideología. Es el menos sabio de los hombres, porque en el camino cambió el saber por el creer.

La metodología de la ideología, por esto mismo, es lógica o dialéctica, pero no en términos abiertos, sino una dialéctica cerrada y obtusa que, como diría Hegel (2010), pone al final una verdad que no puede demostrar en ese espacio donde "todos los gatos son pardos" (p. 71). Es decir, no sigue una dialéctica de la realidad (Wirklichkeit) sino una dialéctica fijada de antemano que no admite negaciones casuales.

La sustitución de la realidad por la ideología sería, entonces, el triunfo de la ideología. En principio, tal triunfo es el que lograron los Estados totalitarios en tanto que pudieron mantenerse en el poder. La superación del totalitarismo, pero en la misma medida su prevención, supone estar atentos a este fenómeno: allí donde la gente renuncie al saber 
por el creer pone en marcha el proceso de su deshumanización y se aplica él mismo las cadenas de la esclavitud.

\section{Referencias}

ABC. (25 de abril, 2006). Mao Zedong provocó la muerte de setenta millones de chinos en tiempos de paz. ABC. https://www.abc.es/cultura/abci-zedong-provocomuerte-setenta-millones-chinos-tiempos-2006042503001421278000590 noticia.html?ref=https:\%252F\%252Fwww.google.com

Academic. (n. f.). Terror rojo (Rusia). Esacademic.com. https://esacademic.com/dic.nsf/eswiki/1448816

Agenzia Fides. (6 de abril, 2004). Las víctimas del totalitarismo comunista de URSS. Fides. http://www.fides.org/es/news/2200Las victimas del totalitarismo comunista de URSS

Althusser, L. y Balibar, E. (1976). La filosofía como arma de la Revolución. En Para leer el capital (M. Harnecker, trad.). Siglo XXI.

Althusser, L. (2006). Ideología y aparato ideológico de Estado: Freud y Lacan. Nueva visión.

Arendt, H. (2002). Los orígenes del totalitarismo (Vol. III; G. Solana, trad.). Alianza Editorial.

Arendt H. (2009) La condición humana (G. Novales, trad.). Paidós.

Arendt, H. (2012). Sobre la revolución (P. Bravo, trad.) Alianza Editorial.

Aristóteles. (2003). Ética a Nicómaco (J. Palli, trad.). Gredos.

Cohen, E. (23 de agosto, 2018). Totalitarismo: recuerdo y reflexión. El mundo. https://www.elmundo.es/opinion/2018/08/23/5b7dgb67ca4741f4278b4599.html

Costelle, D. y Clarke, I. (Directores). (2015). Apocalipsis: Stalin [Serie de televisión]. CC\&C; Ecpad.

Del Rey, M.y Canales, C. (2016). Campos de muerte. Geografía del mal. Edaf.

Hegel, G. W. F. (2005). Lecciones sobre la filosofía de la historia (J. Gaos, trad.). Alianza Editorial. 
Hegel, G. W. F. (2010). Fenomenología del espíritu (A. Gómez Ramos, trad.). Abada.

Kapuscinski, R. (2017). El imperio (A. Orzeszek, trad.). Anagrama.

Mann, M. (2006). El poder autónomo del Estado: sus orígenes, mecanismos y resultados.

Relaciones Internacionales,5,1-43.

https://revistas.uam.es/relacionesinternacionales/article/view/4863

Poulantzas, N. (1979). Estado, poder y socialismo (F. Claudín, trad.). Siglo XXI.

Revilla, R. (2006). La propaganda en el siglo XX. Editorial Astrodata.

Rousseau, J. J. (2011). El contrato social (C. Berges, trad.). Gredos. 